\title{
Influence of Gender and Spawning on Meat Quality of Australian Red Claw Crayfish (Cherax quadricarinatus) Stored at $2{ }^{\circ} \mathrm{C}$
}

\author{
Baohua Kong, Youling L. Xiong, Caodi Fang, Kenneth R. Thompson, Linda S. Metts, Laura A. Muzinic, \\ AND CARL D. WeBSTER
}

\begin{abstract}
Shell-on tails of male (M), nonspawning female (F), and spawning female (SF) Australian red claw crayfish (Cherax quadricarinatus) $(n=270)$ were aerobically stored at $2^{\circ} \mathrm{C}$ up to $10 \mathrm{~d}$ to monitor meat quality changes under a retail condition. Percentage protein of SF muscle was higher $(P<0.05)$ and moisture and ash content lower $(P<$ 0.05 ) than those of $M$ and $F$ muscles. The $\mathrm{pH}$ of muscle changed during storage, with SF generally having a lower value than $\mathrm{M}$ or $\mathrm{F}(P<0.05)$. Lipid oxidation increased during the $1 \mathrm{st} 5 \mathrm{~d}$ and no significant difference existed between the 3 muscle groups. Cooking yield of $S F(91.72 \%)$ at $10 \mathrm{~d}$ was significantly lower than that of $M(96.25 \%)$ or $F(97.81 \%)$, and its muscle shear force was also higher $(P<0.05)$ than $M$ at $0,3,5$, and $7 \mathrm{~d}$ and than $\mathrm{F}$ at 5 and $7 \mathrm{~d}$. Sensory panel results (cooked meat tenderness, juiciness) were significantly correlated with instrumental results (shear force, cooking yield), with SF showing a lower meat tenderness, juiciness, and overall acceptability than $M$ and $F$ samples.

Keywords: gender, meat quality, red claw crayfish, refrigerated storage, spawning
\end{abstract}

\section{Introduction}

$\mathrm{R}_{\mathrm{t}}^{\mathrm{e}}$ ed claw crayfish (Cherax quadricarinatus), a tropical freshwater crustacean species so named for the striking reddish orange patches on the claws of the adult males, is native to Australia but is being commercially cultured in other parts of the world. Red claw crayfish are similar to native American crayfish in their general anatomy, reproduction, and feeding habits. However, red claw crayfish differ from American crayfish in that they have a larger potential size and higher percentage of dress-out (meat), can grow at temperatures ranging from $21^{\circ} \mathrm{C}$ to $32{ }^{\circ} \mathrm{C}$, and the females have multiple annual spawning and higher fecundity (Jones 1989; Masser and Rouse 1997). In a hatchery, mature female red claw crayfish can spawn almost continuously throughout the year if conditions are suitable. Each female will produce 100 to 1000 eggs per spawn depending on her size and general health (Masser and Rouse 1997; Jones 1998).

There have been numerous studies on red claw crayfish nutrient requirement (Figueiredo and Anderson 2003), diet formulation optimization (Muzinic and others 2004; Thompson and others 2004), disease control (Edgerton and others 2002), reproduction and hatching technology (Jerry and others 2005), and productive characteristics (Nguyn and Austin 2004). In contrast, there are limited data available on red claw meat quality, and the influence of gender and spawning condition on the quality attributes of crayfish muscle is completely unknown.

Meat quality as related to palatability is a complex concept that is defined by a number of parameters, including muscle chemical

MS 20060135 Submitted 2/27/2006, Accepted 5/30/2006. Author Kong is with the Dept. of Food Science, Northeast Agricultural Univ., Harbin 150030, China. Authors Xiong and Fang are with the Dept. of Animal and Food Sciences, Univ. of Kentucky, Lexington, KY 40546, U.S.A. Authors Thompson, Metts, Muzinic, and Webster are with the Aquaculture Research Center Kentucky State Univ., Frankfort, KY 40601, U.S.A. Direct inquiries to author Xiong (E-mail: ylxiong@uky.edu).

Published as journal article 06-07-019 with the approval of the Director of Kentucky Agricultural Experiment Station. composition, protein water-binding ability, muscle shear force, lipid oxidation, and flavor components. In a previous study conducted in our laboratory (Tseng and others 2002, 2003), quality changes in red claw tail stored at $0{ }^{\circ} \mathrm{C}$ or subjected to multiple freeze-thaw cycles were investigated. The results showed that red claw muscle was somewhat resistant to protein denaturation and lipid oxidation at the refrigerated temperature, but was susceptible to repeated freezing-thawing. Our more recent study demonstrated that dipping with antioxidant solutions effectively inhibited lipid oxidation and texture deterioration in red claw stored in a $-20^{\circ} \mathrm{C}$ freezer for up to 6 mo (Tseng and others 2005).

The influence of spawning on muscle protein quality of hake (Merluccius hubbsi Marini), although nonshellfish species, has been studied. Pérez-Borla and others (2002) showed that autolytic activity of muscle extracts from prespawning hake was significantly higher than that of postspawning fish. Montecchia and others (1997) found that fillets from prespawning hake stored at $-20{ }^{\circ} \mathrm{C}$ deteriorated more rapidly than postspawning hake in terms of loss of protein solubility. Beas and others (1991) reported that postspawning hake muscle protein was more stable than prespawning hake muscle protein. These reports seemed to suggest that the spawning status of red claw crayfish could also impact the quality of the crayfish meat quality during storage.

The objective of the present study was to determine possible differences in the muscle quality of male, nonspawning female, and spawning female red claw crayfish during refrigerated storage $\left(2^{\circ} \mathrm{C}\right)$. Muscle $\mathrm{pH}$, chemical composition, lipid oxidation, cooking yield, shear force, and sensory characteristics were analyzed in order to identify possible influence of gender and spawning on meat quality stored at the refrigerated temperature.

\section{Materials and Methods}

\section{Materials}

Juvenile red claw crayfish ( $6.3 \pm 3.0 \mathrm{~g}$ stocking weight) were grown in 0.04-ha ponds at Kentucky State Univ. Aquaculture Research 
Center, Frankfort, Kentucky for 12 wk (June 2, 2005 to September $22,2005)$ to a mean live weight of $58.9 \pm 3.6 \mathrm{~g}$. They were fed a wheat/soybean-based diet that contained $76 \%$ whole wheat, $10 \%$ wheat midds, $10 \%$ full-fat soybean meal, $1 \%$ menhaden fish oil, and a mixture of common minerals and vitamins. A total of 270 red claw crayfish [90 males (M), 90 nonspawning females (F), and 90 spawning females (SF)] were randomly collected from a large sample pool of over 2000 live red claw crayfish. SF red claw crayfish, which comprised $14 \%$ (average) of the total female population, were readily identified by the eggs adhered to the underside of the cephalothorax; F red claw crayfish were identified by a pair of genital pores at the base of the 3rd pair (counting from the head) of walking legs; and $\mathrm{M}$ red claw crayfish were recognized by a pair of small genital papillae (projections) at the base of the 5th pair of walking legs. After stunning by chilling in an ice slurry for $2 \mathrm{~min}$, the cephalothorax were removed manually, and the tails (muscle, plus exoskeleton) were placed in iced coolers and shipped to the Univ. of Kentucky Food Protein Research Laboratory within 2 to $3 \mathrm{~h}$ of harvest.

\section{Storage and sample preparation}

Shell-on tails of red claw crayfish were separately placed in styrofoam trays (10 in each), over-wrapped with a PVC film, and stored in a $2{ }^{\circ} \mathrm{C}$ walk-in cooler for $0,1,3,5,7$, and $10 \mathrm{~d}$. During storage, fluorescent lights in the cooler were kept on to simulate supermarket retail display. At the end of each storage period, 3 tails from each animal group were deshelled and the pooled muscles were finely chopped by blending with a micro Waring blendor for proximate composition, $\mathrm{pH}$, and lipid peroxidation analysis. Also for each storage time, 7 tails with shell on were cooked for cooking yield and muscle shear force measurements. On 0 , 5, and $10 \mathrm{~d}$ of postmortem storage, an additional 10 red claw crayfish were used for sensory panel evaluation.

\section{Proximate analysis}

The analysis was done with a minimum of 3 muscle samples, and each sample was analyzed in triplicate. Protein was measured by the combustion method using a Model FP2000 Protein Analyzer (Leco Corp., St Joseph, Mich., U.S.A.). A 6.25 nitrogen-to-protein conversion factor was used for the calculation. Moisture was determined by drying the sample in a $105^{\circ} \mathrm{C}$ oven to a constant weight. Crude lipid was measured by petroleum ether extraction in a Soxhlet apparatus (1043 Soxtec System, HT-Tecator, Fisher Scientific Co., Fair Lawn, N.J., U.S.A.) for $2.5 \mathrm{~h}$ at $60^{\circ} \mathrm{C}$. Ash content was measured as the residue after overnight heating of the samples in a $600^{\circ} \mathrm{C}$ muffle furnace (Fisher Scientific Co.).

\section{pH}

An aliquot of $3 \mathrm{~g}$ of minced muscle was dispersed in $30 \mathrm{~mL}$ of deionized distilled water with a low-foam homogenizer (Brinkman Instruments, Inc., Westbury, N.Y., U.S.A.). The $\mathrm{pH}$ of the slurry was measured using an $\mathrm{AB} 15 / 15^{+} \mathrm{pH}$ meter with a glass $\mathrm{pH}$ electrode (Fisher Scientific Co.). The pH was measured on 3 muscle samples, and each measurement was done in triplicate.

\section{Thiobarbituric acid-reactive substances (TBARS)}

Lipid oxidation was evaluated by TBARS according to Sinnhuber and Yu (1977) with slight modifications as described by Wang and Xiong (2005). After reaction with TBA, the sample solution was mixed with chloroform (1:1 ratio, v/v), vortexed, and subsequently centrifuged at $1800 \times g$ for $10 \mathrm{~min}$. The TBARS value, expressed as $\mathrm{mg}$ of malonaldehyde $/ \mathrm{kg}$ of muscle sample, was calculated using the following equation:
$\operatorname{TBARS}(\mathrm{mg} / \mathrm{kg})=\left(A_{532} / W_{\mathrm{s}}\right) 9.48$

where $A_{532}$ was the absorbance ( $532 \mathrm{~nm}$ ) of the assay solution, $W_{\mathrm{s}}$ was the meat sample weight (g), and "9.48" was a constant derived from the dilution factor and the molar extinction coefficient $\left(152000 \mathrm{M}^{-1} \mathrm{~cm}^{-1}\right)$ of the red, TBA reaction product. The assay was carried out with 3 muscle samples, and each sample was analyzed in triplicate.

\section{Cooking}

Seven shell-on tails were individually weighed and then cooked in boiling water $\left(100{ }^{\circ} \mathrm{C}\right)$ for exactly $2 \mathrm{~min}$, chilled to room temperature $\left(21^{\circ} \mathrm{C}\right)$ for $15 \mathrm{~min}$, and weighed again. Cooking yield (\%) was expressed as cooked shell-on weight divided by raw shell-on weight of red claw crayfish then multiplying by 100 . After cooking yield measurement, the meat from each individual tail was subjected to instrumental textural analysis and taste panel evaluation as described below.

\section{Instrumental textural analysis}

Each of the 7 cooked, deshelled, red claw crayfish tails was weighed before being subjected to individual textural analysis. A Model 4301 Instron Universal Testing Instrument (Instron Corp., Canton, Mass., U.S.A.) with a Warner-Bratzler shearing device attached to the load cell ( $1000 \mathrm{~N}$ capacity) was used to measure the muscle shear force. The tail was placed in a transverse position to the blade so that the blade would cut through the 1st major muscle segment from the anterior of the cooked tail across the muscle fibers (Tseng and others 2005). The cross-head speed of the Instron was 20 $\mathrm{mm} / \mathrm{min}$, and the 1st major peak (usually the highest, which represented the maximal shear force required to cut the muscle sample) was recorded. Shear force values $(\mathrm{N})$ for individual red claw crayfish were normalized based on the weight (g) of the tails, and expressed as force per sample unit weight (N/g) to eliminate size effects (Srinivasan and others 1997).

\section{Sensory evaluation}

Sensory evaluation of cooked red claw crayfish (10 for each storage time) was conducted by an 8-member taste panel that consisted of selected faculty, staff, and graduate students who had prior experience with muscle food sensory tests. An Institutional Review Board (IRB) approval was obtained for the sensory evaluation. The panel was trained in preliminary sessions to identify the specific sensory traits of red claw crayfish using 20 other cooked red claw crayfish. A total of 3 panel sessions, corresponding to 0,5 , and $10 \mathrm{~d}$ of storage, were conducted. The sensory evaluation room contained partitioned booths each illuminated with red lights. No visible sign of physical or psychological anomaly was observed on any of the panelists during the sensory sessions, and the performance of each panelist was considered satisfactory.

Cooked tail meat was cut into approximately $1 \mathrm{~cm}^{3}$ bits and mixed well before serving. Samples (M, F, and SF) were randomized in all panel sessions. A "warm-up" sample (pooled meat from 5 to 7 red claw crayfish) at the beginning of every panel session was evaluated as a reminder of the score range for each sensory trait. The following sensory characteristics were evaluated: lobster flavor, offflavor, rancidity, tenderness, and juiciness. Scores were assigned on an evaluation sheet that was marked with a 7-point line scale: for lobster flavor, $1=$ mild, $7=$ intense; for off-odor, $1=$ nondetectable, 7 = intense; for rancidity, $1=$ nondetectable, $7=$ intense; for tenderness, $1=$ tough, $7=$ tender; and for juiciness, $1=$ dry, $7=$ juicy. Panelists marked on the scale (numbered 1 to 7 ) where they felt best described the sensory attributes. As consumers, panelists were 
also asked for their opinion on acceptability of the red claw crayfish samples evaluated, that is, overall acceptability with $1=$ low and $7=$ high.

\section{Statistical analysis}

Data were analyzed using the General Linear Models procedure of the Statistix 7.0 software package (Analytical Software, St Paul, Minn., U.S.A.) for microcomputers. Analysis of variance (AOV) was done to determine the significance of the main effects (gender, spawning, storage time). Significant differences $(P<0.05)$ between means were identified using least significant difference procedures. Regression analysis was run to determine possible correlations between instrumental and sensory panel results.

\section{Results and Discussion}

\section{Proximate analysis}

The tail weight of M red claw crayfish was slightly greater $(P<$ 0.05) than that of F but was similar to that of SF (Table 1). There were no significant differences in the percentage moisture, protein, lipid, and ash between $\mathrm{M}$ and $\mathrm{F}$ muscles. The results were in agreement with those reported by Thompson and others (2004). The percentage protein of SF muscle was higher $(P<0.05)$, but its moisture and ash content was lower $(P<0.05)$, than those of $\mathrm{M}$ and $\mathrm{F}$. The higher protein content in SF muscle may be due to the nutritional need for spawning; and the lower ash content maybe due to some mineral transfer to the spawn during the period of spawning. Muscle lipid content was quite low $(<0.18 \%$ on a wet weight) for all 3 crayfish groups.

\section{pH changes}

The $\mathrm{pH}$ values of tail muscle samples analyzed on different postmortem storage times are displayed in Figure 1. The pH initially dropped (to a minimum in 3 to $5 \mathrm{~d}$ ) followed by an increase during subsequent storage, a pattern that was similar for all 3 crayfish groups. However, the $\mathrm{M}$ and $\mathrm{F}$ muscles had significantly higher $\mathrm{pH}$ than SF during the 1 st $3 \mathrm{~d}$, but on days 5 and 7 , F muscle had a higher $\mathrm{pH}$ than $\mathrm{M}$ and $\mathrm{SF}(P<0.05)$. Overall, spawning lowered the muscle $\mathrm{pH}$, and the difference between $\mathrm{F}$ and SF surpassed that existing between $\mathrm{M}$ and $\mathrm{F}$. The $\mathrm{pH}$ level in crustacean muscle is normally higher than that of fish and mammalian species because the former had a higher content of nonprotein nitrogenous compounds (Shahidi 1994). Gonçalves and others (2003) studied quality changes of deepwater pink shrimp (Parapenaeus longirostris) and showed that the initial $\mathrm{pH}$ value of the pink shrimp was around 7.1, and the $\mathrm{pH}$ increased during storage.

Table 1-Proximate analysis of the tail muscle of male, female, and spawning female red claw crayfish

\begin{tabular}{lrrr}
\hline & Male & Female & \multicolumn{1}{c}{$\begin{array}{c}\text { Spawning } \\
\text { female }\end{array}$} \\
\hline Shell-on tail weight $(\mathrm{g})^{\mathrm{a}}$ & $16.79 \pm 0.72^{\mathrm{b}}$ & $14.86 \pm 0.56^{\mathrm{c}}$ & $16.36 \pm 0.57^{\mathrm{bc}}$ \\
Wet muscle basis & & & \\
$\quad$ Moisture (\%) & $81.01 \pm 0.27^{\mathrm{b}}$ & $81.15 \pm 0.25^{\mathrm{b}}$ & $79.42 \pm 0.10^{\mathrm{c}}$ \\
Protein (\%) & $17.61 \pm 0.03^{\mathrm{c}}$ & $17.48 \pm 0.01^{\mathrm{c}}$ & $18.05 \pm 0.02^{\mathrm{b}}$ \\
Lipid (\%) & $0.13 \pm 0.02^{\mathrm{c}}$ & $0.18 \pm 0.00^{\mathrm{b}}$ & $0.17 \pm 0.01^{\mathrm{b}}$ \\
Ash (\%) & $1.14 \pm 0.00^{\mathrm{b}}$ & $1.16 \pm 0.00^{\mathrm{b}}$ & $1.09 \pm 0.02^{\mathrm{c}}$ \\
Dry matter basis & & & \\
Protein (\%) & $92.67 \pm 0.12^{\mathrm{b}}$ & $92.72 \pm 0.06^{\mathrm{b}}$ & $87.71 \pm 0.08^{\mathrm{c}}$ \\
Lipid (\%) & $0.70 \pm 0.10^{\mathrm{c}}$ & $0.97 \pm 0.02^{\mathrm{b}}$ & $0.81 \pm 0.02^{\mathrm{c}}$ \\
Ash (\%) & $6.01 \pm 0.00^{\mathrm{b}}$ & $6.15 \pm 0.02^{\mathrm{b}}$ & $5.30 \pm 0.12^{\mathrm{c}}$ \\
\hline aThe weight represented the mean \pm standard deviation of 40 tails. \\
b,c Means in the same row with different superscript letters differ significantly \\
$(P<0.05)$.
\end{tabular}

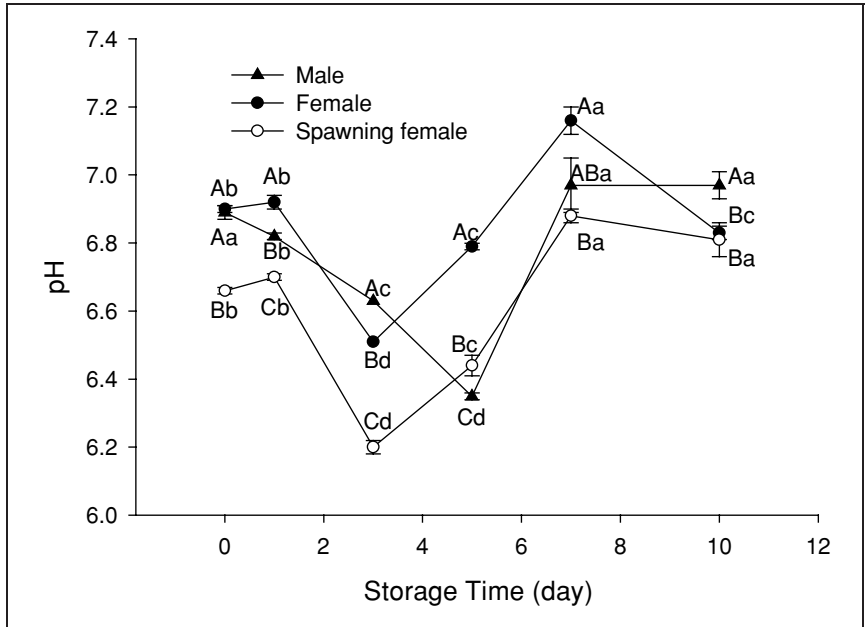

Figure 1-Influence of gender and spawning on the $\mathrm{pH}$ values of raw red claw crayfish muscle stored at $2{ }^{\circ} \mathrm{C}$ for various periods. Each data point represents the mean of 3 replications. Means in the same crayfish group (line) with different lowercase letters (a to d) differ significantly $(P<0.05)$; means between crayfish groups on the same days with different uppercase letters (A to $C$ ) differ significantly $(P<0.05)$.

The death of an animal initiates major changes in the biochemical conditions in the muscle tissue. A pH decline immediately postmortem is generally ascribed to the accumulation of lactic acid due to glycolysis, but it is not clear why the red claw crayfish muscle $\mathrm{pH}$ continued to drop from day 1 to day 3 or day 5 . Nevertheless, the subsequent $\mathrm{pH}$ increase may have resulted from the formation of amine compounds (for example, ammonia) from microbial and enzymatic activity (Finne 1982; Aberle and others 2001). Alternatively, Pierson and Fox (1976) suggested an altered ion-protein interaction due to an increased influx of $\mathrm{K}^{+}$as a possible cause for postmortem $\mathrm{pH}$ elevation. So far, there is no literature report on the $\mathrm{pH}$ change in spawning crustacean or fish during refrigerated storage. The reasons that spawning female red claw crayfish had a reduced muscle $\mathrm{pH}$ could be due to certain special physiological conditions and/or muscle biochemical metabolisms that arose during spawning and continued after death. In our preliminary study, we noted slower postmortem protein degradation (autolysis) in refrigerated SF muscle than in F or M muscle (Kong and Xiong, unpublished data). The suppressed proteolysis (thus, a reduced release of amine groups or compounds) may be partially responsible for the lower $\mathrm{pH}$ of SF muscle.

\section{Lipid oxidation}

Oxidation is a leading cause for quality deterioration during processing and storage of muscle foods. Quality losses in oxidized meat products are generally characterized by flavor deterioration, discoloration, destruction of nutrients, and possible formation of toxic compounds. Since lipid oxidation was implicated in textural deterioration in many fish species (Shenouda 1980), it was monitored during storage in this study. When stored at refrigerated temperature, lipids in meat oxidize and unsaturated fatty acids form hydroperoxides that are subsequently cleaved to secondary reaction products (Frankel 1998). As shown in Figure 2, TBARS in all 3 crayfish groups increased $(P<0.05)$ during the 1 st $5 \mathrm{~d}$ and then decreased. The decline, which has also been observed in other studies, may be attributed to the reaction of malonaldehyde with proteins and other muscle constituents (Buttkus 1967; Park and others 2006). No difference in TBARS was observed between $\mathrm{M}$ and $\mathrm{F}$ and between $\mathrm{F}$ and SF for any of the storage periods. 
These results were in concert with the findings on freshwater prawn presented by Reddy and others (1981). Tseng and others (2002) reported that TBARS in red claw crayfish muscle stored at $0{ }^{\circ} \mathrm{C}$ increased steadily from $0.341 \mathrm{mg} / \mathrm{kg}$ on day 0 to $1.492 \mathrm{mg} / \mathrm{kg}$ on day 14 . The values were lower than those from the present study. The reason for the difference may be that in this study, red claw crayfish were stored at a higher temperature $\left(2{ }^{\circ} \mathrm{C}\right.$ instead of the more critical $0{ }^{\circ} \mathrm{C}$ ) and the samples packaged with a transparent PVC film were constantly exposed to the fluorescent lights, rendering the samples more susceptible to lipid oxidation.

\section{Cooking yield}

Cookingyield of red claw meat was affected by gender and spawning and changed during storage $(P<0.05)$ (Figure 3$)$. In $\mathrm{M}$ and $\mathrm{F}$, the cooking yields were $94.6 \%$ and $95.2 \%$ on $0 \mathrm{~d}$, and increased $(P<0.05)$ to $96.3 \%$ and $97.8 \%$ after $10 \mathrm{~d}$. Throughout storage, the cooking yield

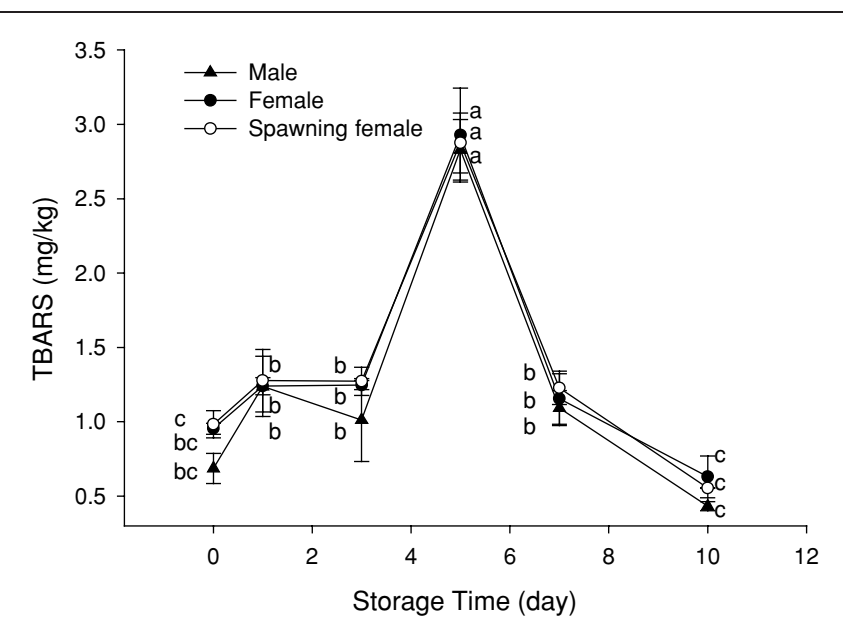

Figure 2-The TBARS levels in raw red claw crayfish stored at $2{ }^{\circ} \mathrm{C}$ for various periods. Each data point represents the mean of 3 replications. Means in the same crayfish group (line) with different lowercase letters (a to c) differ significantly $(P<0.05)$. No significant difference was found between the 3 crayfish groups at any of the storage times.

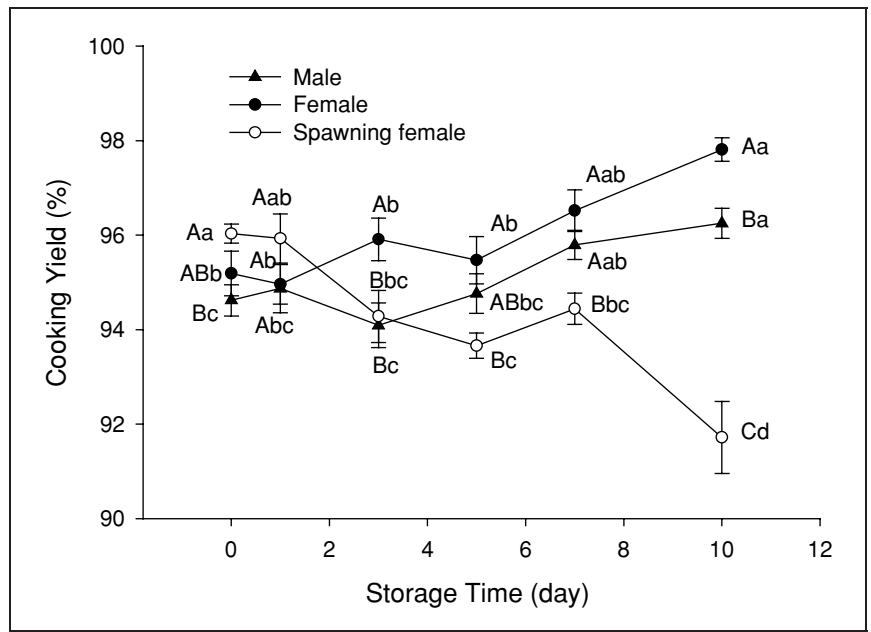

Figure 3-Cooking yield of red claw crayfish after storage at $2{ }^{\circ} \mathrm{C}$ for various periods. Each data point represents the mean of 7 replications. Means in the same crayfish group (line) with different lowercase letters (a to d) differ significantly ( $P<0.05)$; means between crayfish groups on the same days with different uppercase letters (A to C) differ significantly (P $<0.05)$. of $\mathrm{F}$ appeared to be higher than $\mathrm{M}$, but the apparent difference was nonsignificant except on day 3 and day 10. The cooking yield of SF was $96.0 \%$ on day 0 and $95.9 \% 1 \mathrm{~d}$ later, and then decreased quickly to $91.7 \%$ by day 10 , which was significantly lower than $\mathrm{M}$ and $\mathrm{F}$ $(P<0.05)$. The capability of red claw crayfish muscle to retain moisture upon cooking is attributed to water-binding by muscle proteins and water-holding within the muscle myofibril matrix (Van Lacck 1999). Postmortem changes in muscle proteins, for example, cleavage of peptide bonds by endogenous proteases, would result in an increased net charge of proteins, thus, a stronger protein-water interaction. This may explain the improved cooking yield in $\mathrm{M}$ and $\mathrm{F}$ muscle samples stored for more than 7 or $10 \mathrm{~d}$.

\section{Warner-Bratzler shear force}

Significant differences existed between M, F, and SF in their shear force values during postmortem storage. SF muscle had a higher shear force than $\mathrm{M}$ muscle at day 0 and than F muscle at day 3 , and the difference remained over much of the storage time, that is, higher than $\mathrm{M}$ at $0,3,5$, and $7 \mathrm{~d}$, and higher than $\mathrm{F}$ at 5 and $7 \mathrm{~d}(P<0.05)$ (Figure 4). Moreover, while both $\mathrm{M}$ and $\mathrm{F}$ showed some fluctuations in the shear force change during storage, shear force of SF muscle continued to increase through $5 \mathrm{~d}$ and then decreased through the latter half of the storage time. On day 10 , the muscle shear values for all the 3 groups were identical $(P>0.05)$.

The higher shear force of SF muscle probably resulted from a higher degree of protein aggregation implicated by the reduced cooking yield. It was noted that the $\mathrm{pH}$ of SF muscle was lower than the $\mathrm{pH}$ of $\mathrm{M}$ and $\mathrm{F}$ muscles on most of the sampling days (Figure 1). With a muscle $\mathrm{pH}$ closer to the isoelectric point of myosin (pH 5.1), SF protein would be more prone to hydrophobic aggregation upon cooking when compared with $\mathrm{M}$ or F proteins. Another possible reason for the shear force difference was that SF muscle contained less proteolytic activity postmortem than $\mathrm{M}$ and $\mathrm{F}$ muscle, which was observed in our preliminary study (Kong and Xiong, unpublished data). Therefore, SF red claw crayfish muscle would have a more intact, thus, tougher, muscle structure. The shear force changes in the 3 crayfish groups-an initial increase followed by a subsequent reduction-may be explained by 2 opposing effects, namely tissue-toughening due to protein denaturation and

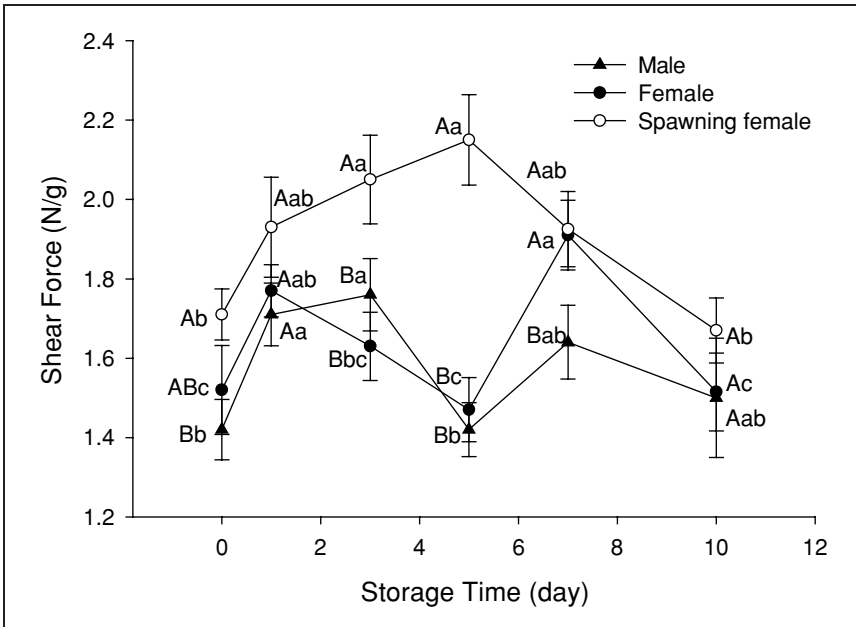

Figure 4-Shear force of cooked red claw crayfish after storage at $2{ }^{\circ} \mathrm{C}$ for various periods. Each data point represents the mean of 7 replications. Means in the same crayfish group (line) with different lowercase letters (a to c) differ significantly ( $P<0.05)$; means between crayfish groups on the same days with different uppercase letters (A, B) differ significantly $(P<0.05)$. 
tissue-softening due to proteolysis. At the prolonged storage stage, proteolysis would seem to be predominant and offset the counteraction of tissue-toughening factor (Tseng and others 2002).

\section{Sensory panel evaluation}

The sensory panel results of cooked red claw crayfish meat are summarized in Table 2. All 3 crayfish groups exhibited changes in sensory characteristics during storage. The lobster flavor was not affected $(P<0.05)$ either by gender or by storage time, and the panel detected essentially no rancidity in all samples even after $10 \mathrm{~d}$. Yet, the panel identified a low-level off-flavor in all 3 crayfish groups, notably toward the end the refrigerated storage. Tenderness did not show significant changes during storage for $\mathrm{M}$ and $\mathrm{F}$ muscles, but decreased $(P<0.05)$ for $\mathrm{SF}$ after $5 \mathrm{~d}$. Juiciness scores for $\mathrm{M}$ and $\mathrm{F}$ tended to be greater than that of SF, and the difference between the 10-d samples was significant. The deterioration in some of the quality attributes in SF muscle during storage led the panel members to conclude that the SF tail meat stored for $10 \mathrm{~d}$ at $2{ }^{\circ} \mathrm{C}$ was less acceptable than $\mathrm{M}$ and $\mathrm{F}$ tail meat.

\section{Relationship between meat quality factors}

When all the samples tested were pooled to perform regression analysis, the $\mathrm{pH}$ was found not to be correlated $(P>0.05)$ with muscle shear force or with tenderness although it was weakly correlated with cooking yield $(r=0.466, P<0.05)$ and juiciness $(r=$ $0.415, P<0.10$ ) (Table 3 ). Because both cooking yield and juiciness are governed by protein-water interaction, an increase in muscle $\mathrm{pH}$-which would result in more net charges on protein-would allow more water to be immobilized in meat through hydrogen bonds. Cooking yield was not correlated with shear force $(P>0.05)$, and the lack of correlation suggested that red claw meat toughness was determined by factors other than the ability of protein or the myofibril matrix to bind water.

When data from instrumental analyses were compared with those from the sensory panel evaluation, significant relationships were noted between shear force and tenderness $(r=-0.837, P<0.01)$

Table 2-Sensory evaluation of cooked red claw crayfish

\begin{tabular}{|c|c|c|c|}
\hline $\begin{array}{l}\text { Sensory } \\
\text { attribute }^{a}\end{array}$ & Male & Female & $\begin{array}{l}\text { Spawning } \\
\text { female }\end{array}$ \\
\hline \multicolumn{4}{|l|}{ Day 0} \\
\hline Lobster flavor & $4.25 \pm 0.25^{\mathrm{b}}$ & $3.88 \pm 0.23^{b}$ & $4.00 \pm 0.26^{b}$ \\
\hline Off-flavor & $1.25 \pm 0.16^{\mathrm{bcd}}$ & $1.00 \pm 0.00^{d}$ & $1.13 \pm 0.13^{c d}$ \\
\hline Rancidity & $1.13 \pm 0.13^{b}$ & $1.00 \pm 0.00^{\mathrm{b}}$ & $1.00 \pm 0.00^{\mathrm{b}}$ \\
\hline Tenderness & $5.34 \pm 0.18^{b}$ & $5.50 \pm 0.19^{b}$ & $5.25 \pm 0.31^{b}$ \\
\hline & $06 \pm$ & $5.44 \pm 0.18^{b}$ & $4.75 \pm 0.25^{\mathrm{bcc}}$ \\
\hline cceptability & $5.25 \pm 0.37^{b}$ & $5.50 \pm$ & $0.38^{\mathrm{b}}$ \\
\hline \multicolumn{4}{|c|}{ Day 5} \\
\hline Lobster flavor & $3.91 \pm 0.36^{b}$ & $3.64 \pm 0.32^{\mathrm{b}}$ & $3.72 \pm 0.27^{b}$ \\
\hline & bcd & $1.36=$ & $0.13^{\mathrm{bcc}}$ \\
\hline & $1.09 \pm$ & $1.09 \pm$ & $10^{\mathrm{b}}$ \\
\hline Teno & $5.32 \pm c$ & $5.27 \pm$ & $0.26^{c}$ \\
\hline Juicin & $4.86 \pm 0.28^{\mathrm{bcd}}$ & $4.91 \pm 0.37^{\mathrm{bcd}}$ & $4.32 \pm 0.30^{c d}$ \\
\hline Overall acceptability & $5.23 \pm 0.22^{\mathrm{b}}$ & $5.27 \pm 0.28^{\mathrm{b}}$ & $5.00 \pm 0.14^{\mathrm{bc}}$ \\
\hline \multicolumn{4}{|c|}{ Day 10} \\
\hline Lobster flavor & $3.93 \pm 0.17^{b}$ & $4.00 \pm 0.44^{b}$ & $4.00 \pm 0.44^{b}$ \\
\hline Off-flavor & $1.71 \pm 0.47^{b}$ & $1.71 \pm c$ & $.30^{\mathrm{bc}}$ \\
\hline Ranc & $1.29 \pm 0.27^{b}$ & $1.14 \pm 0.14^{\mathrm{b}}$ & $1.14 \pm 0.14^{\mathrm{b}}$ \\
\hline Tend & $5.14 \pm 0.32^{\mathrm{b}}$ & $5.07 \pm 0.35^{\mathrm{b}}$ & $4.57 \pm 0.28^{c}$ \\
\hline Juiciness & $4.86 \pm 0.34^{\mathrm{bcd}}$ & $4.79 \pm 0.21^{\mathrm{bcd}}$ & $4.29 \pm 0.29^{d}$ \\
\hline Overall acceptability & $4.79 \pm 0.53^{\mathrm{bc}}$ & $4.29 \pm 0.47^{c d}$ & $3.93 \pm 0.35^{d}$ \\
\hline
\end{tabular}

a Lobster flavor $=1$ (mild) to 7 (intense); off-flavor $=1$ (nondetectable) to 7 (intense); rancidity $=1$ (nondetectable) to 7 (intense); tenderness $=1$ (tough) to 7 (tender); juiciness $=1$ (dry) to 7 (juicy); overall acceptability $=1$ (low) to 7

${ }_{b-\mathrm{d}}$ Means in the same row with different superscripts differ significantly ( $P<$ 0.05).
Table 3 - Correlation coefficients ( $r$ ) among selected quality factors of red claw crayfish meat

\begin{tabular}{lccccc}
\hline Factor & pH & $\begin{array}{c}\text { Cooking } \\
\text { yield }\end{array}$ & $\begin{array}{c}\text { Shear } \\
\text { force }\end{array}$ & Tenderness & Juiciness \\
\hline pH & - & $0.466^{*}$ & -0.245 & 0.342 & 0.415 \\
Cooking yield & - & & -0.333 & $0.540^{*}$ & $0.491^{*}$ \\
Shear force & - & & & $-0.837^{* *}$ & $-0.679^{* *}$ \\
Tenderness & - & & & & $0.801^{* *}$ \\
Juiciness & - & & & & \\
\hline
\end{tabular}

$* P<0.05$.

$* * P<0.01$.

and between shear force and juiciness $(r=-0.679, P<0.01)$. A weak correlation was also observed between cookingyield and tenderness ( $r=0.540, P<0.05)$, and between cooking yield and juiciness $(r=$ $0.491, P<0.05)$. Within the sensory analysis, tenderness was highly correlated with juiciness $(r=0.801, P<0.01)$. Thus, Warner-Bratzler shear force could be used to predict tenderness and juiciness of red claw crayfish meat with reasonable accuracy.

Correlation analysis within individual crayfish groups also showed significant relationships between instrumental and panel results. For example, SF had a lower shear force and a lower cooking yield than $\mathrm{M}$ and $\mathrm{F}$, and these gender and spawning effects were held true also for tenderness and juiciness evaluated by the taste panel (data not shown). However, although the level of lipid oxidation products (TBARS) increased slightly during storage, no corresponding rancidity could be detected by the sensory panel. It could be that the TBARS level in red claw crayfish muscle studied was below the detection threshold ( $3 \mathrm{mg} / \mathrm{kg}$ ) as established by Sinnhuber and Yu (1958). Whether the small amount of uncharacteristic off-flavor detected by the sensory panel was related to the small production of TBARS remains unclear.

\section{Conclusion}

$\mathrm{R}$ esults from this study indicated that the spawning condition of Australian red claw crayfish influenced meat quality during refrigerated storage. In general, spawning female red claw crayfish had an inferior meat quality compared to male and nonspawning female red claw crayfish, that is, a reduced cooking yield, a higher shear force, and a lower sensory tenderness, juiciness, and overall acceptability. Meat quality differences between male and nonspawning females tended to be inappreciable. The meat quality variations observed between the 3 crayfish groups were not significantly correlated with the raw muscle $\mathrm{pH}$, but tenderness and juiciness of cooked red claw crayfish could be reasonably predicted from the cooking yield and Warner-Bratzler shear force. Despite the effect of spawning and gender, red claw crayfish meat appeared to be stable during refrigerated storage in both textural and flavor properties.

\section{Acknowledgments}

The authors thank Dr. James Moy for his advice on sensory and textural analysis of the red claw meat. This research was funded, in part, by a USDA 1890 Institution Capacity Building Grant nr 2003-3881413954, and by a USDA CSREES Grant nr 2004-35503-14122. Author Kong was on sabbatical leave which was supported, in part, by a Studying Abroad Grant of the Northeast Agricultural Univ., China.

\section{References}

Aberle ED, Forrest JC, Gerrard DE, Mills EW. 2001. Conversion of muscle to meat and development of meat quality. In: Principles of meat science, 4 th ed. Dubuque, Iowa: Kendall/Hunt Publishing Company. p 83-108.

Beas VE, Wagner JR, Añón MC, Crupkin M. 1991. Thermal denaturation in fish muscle proteins during gelling: effect of spawning condition. J Food Sci 56:281-4.

Buttkus H. 1967. The reaction of myosin with malonaldehyde. J Food Sci 32:432-4.

Edgerton BF, Evan LH, Stephens FJ, Overstreet RM. 2002. Synopsis of freshwater crayfish diseases and commensal organisms. Aquaculture 206:57-135. 
Figueiredo MSRB, Anderson AJ. 2003. Ontogenetic changes in digestive proteases and carbohydrases from the Australian freshwater crayfish, redclaw Cherax quadricarinatus (Crustacea, Decapoda, Parastacidae). Aquac Res 34:1235-9.

Finne G. 1982. Enzymatic ammonia production in shrimp held on ice. In: Martin RE Flick GJ, Hebard CE, Ward DR, editors. Chemistry and biochemistry of marine food products. Westport, Conn.: AVI Publishing Co. Inc. p 323-31.

Frankel EN. 1998. Lipid oxidation. Dundee, Scotland: The Oil Press.

Gonçalves AC, López-Caballero ME, Nunes ML. 2003. Quality changes of deepwater pink shrimp (Parapenaeus longirostris) packed in modified atmosphere. J Food Sci 68:2586-90.

Jerry DR, Jurvis IW, Piper LR, Dennis CA. 2005. Selection for faster growth in the freshwater crayfish Cherax destructor. Aquaculture 247:169-76.

Jones CM. 1989. The biology and acquaculture potential of Cherax quadricarinatus. Final report submitted by the Queensland Dept. of Primary Industries to the Reserve Bank of Australia Rural Credits Development project nr QDPI/8860.

Jones CM. 1998. Redclaw crayfish. In: Hyde KW, editor. The new rural industries-a handbook for farmers and investor. Canberra, Australia: Rural Industries Research and Development Corporation. p 127-33.

Masser MP, Rouse DB. 1997. Australian red claw crayfish. SRAC publication nr 244.

Montecchia CL, Roula SI, Roldán H, Pérez-Borla O, Cruplin M. 1997. Biochemical and physicochemical properties of actomyosin from frozen pre- and postspawned hake. J Food Sci 62:491-5.

Muzinic LA, Thompson KR, Morris A, Webster CD, Rouse DB, Manomaitis L. 2004. Partial and total replacement of fish meal with soybean meal and brewer's grains with yeast in practical diets for Australian red claw crayfish Cherax quadricarinatus. Aquaculture 230:359-76.

Nguyn TTT, Austin CM. 2004. Inheritance of molecular markers and sex in the Australian freshwater crayfish, Cherax destructor clark. Aquac Res 35:1328-38.

Park D, Xiong YL, Alderton AL, Ooizumi T. 2006. Biochemical changes in myofibrillar protein isolates exposed to three oxidizing systems. J Agric Food Chem 54: forthcoming.

Pérez-Borla O, Rours SI, Montecchia CL, Rold H, Crupkin M 2002. Proteolytic activity of muscle in pre- and post-spawning hake (Merluccius hubbsi marini) after frozen storage. Lebensmit Wissens Technol 35:325-30.

Pierson CJ, Fox JD. 1976. Effect of postmortem ageing time and temperature on $\mathrm{pH}$, tenderness and soluble collagen fractions in bovine longissimus muscle. J Anim Sci 43:1206-10.
Reddy SK, Nip WK, Tang CS. 1981. Change in fatty acid and sensory quality of fresh water prawn (Macrobrachium rosenberbii) stored under frozen conditions. J Food Sci 46:353-6.

Shahidi F. 1994. Seafood proteins and preparation of protein concentrates. In: Shahidi F, Botta JR, editors. Seafoods: chemistry, processing technology and quality. London: Blackie Academic \& Professional. p 3-9.

Shenouda SYK. 1980. Theories of protein denaturation during frozen storage of fish flesh. Adv Food Res 26:275-311.

Sinnhuber RO, Yu TC. 1958. 2-Thiobarbituric acid method for the measurement of rancidity in fishery products II. The quantitative determination of malonaldehyde. Food Technol 12:9-12.

Sinnhuber RO, Yu TC. 1977. The 2-thiobarbituric acid reaction, an objective measure of the oxidative deterioration occurring in fats and oils. J Jpn Oil Chem Soc 25 259-67.

Srinivasan S, Xiong YL, Blanchard SP, Tidwell JH. 1997. Physicochemical changes in prawns (Machrobrachium rosenbergii) subjected to multiple freeze-thaw cycles. Food Sci 62:123-7.

Thompson KR, Muzinic LA, Yancey DH, Webster CD, Rouse DB, Xiong YL. 2004. Growth, processing measurements, tail meat yield, and tail meat proximate composition of male and female Australian red claw crayfish, Cherax quadricarinatus, stocked into earthen ponds. J Appl Aquac 16:117-29.

Tseng YC, Xiong YL, Webster CD, Thompson KR, Muzinic LA. 2002. Quality changes in Australian red claw crayfish, Cherax quadricarinatus, stored at $0{ }^{\circ} \mathrm{C}$. J Appl Aquac 12:53-66.

Tseng YC, Xiong YL, Feng J, Ramirez-Suarez JC, Webster CD, Thompson KR, Muzinic LA. 2003. Quality changes in Australian red claw crayfish (Cherax quadricarinatus) subjected to multiple freezing-thawing cycles. J Food Quality 26:285-98.

Tseng YC, Xiong YL, Webster CD. 2005. The preservation of the quality of the muscle in frozen Australian red claw crayfish (Cherax quadricarinatus) by pre-storage antioxidant dipping treatments. Int J Food Sci Technol 40:841-8.

Van Lacck RLJM. 1999. The role of proteins in water-holding capacity of meat. In: Xion YL, Ho CT, Shahidi F, editors. Quality attributes of muscle foods. New York: Kluwer Academic/Plenum Publishers. p 309-18.

Wang LL, Xiong YL. 2005. Inhibition of lipid oxidation in cooked beef patties by hy drolyzed potato protein is related to its reducing and radical scavenging ability. Agric Food Chem 53:9186-92. 